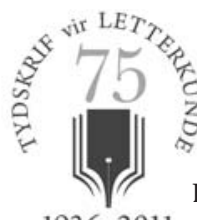

Henriette Roos

Henriette Roos is'n professor emerita, Departement Afrikaans, Universiteit van Suid-Afrika 1936-2011 E-pos: henrietteroos@telkomsa.net

\title{
Tydskrif vir Letterkunde: 75 jaar
}

Toe Hein Willemse my gevra het om die "geleentheidstoespraak" by hierdie verjaardagviering te lewer, kon ek nie anders nie as om te wonder: "hoekom ek, hoekom nou?" Maar ons het gelukkig ooreengekom dat hierdie "toespraak" eintlik net my subjektiewe indrukke omtrent die verhouding tussen die Tydskrif vir Letterkunde (hierna: Tydskrif) en momente in die Afrikaanse letterkunde gaan weergee. Subjektief, veral omdat ek dalk een van die laastes van' $n$ bepaalde generasie is en, ek weet nie of Hein my daaromtrent heeltemal geglo het nie, ek my ook op een of ander wyse kan beroep op'n persoonlike band met elkeen van die ses redakteurs tot dusver: van Van den Heever tot by Willemse. Daaroor later.

In die jongste uitgawe van die Tydskrif (48:2, Lente) word baie insiggewende kommentaar en inligting oor die geskiedenis van Tydskrif gegee deur die redaksionele kommentaar van Willemse (5-12) en 'n informatiewe ondersoeksverslag van Jan Stander (13-30). Dit is opmerklik hoe, wanneer hierdie twee tekste saamgelees word, 'n historiese terugblik op maar ook' $n$ toekomsvisie vir die tydskrif uitgespel word. En dit is'n perspektief wat openhartig spreek van die besondere aard van Tydskrif oor die verloop van 'n driekwart eeu; van laagtepunte en dowwe kolle, maar ook van groot prestasies en integriteit. Dit is teen die agtergrond van hierdie beskouings wat ek'n persoonlike mening wil oordra.

Met sy professorale intreerede op Donderdag 1 September 2011, was dit Willie Burger se aanwysing van wat hy genoem het "die verdwyning van die humanisme" as een van die groot bewegings binne die wêreld van die letterkunde gedurende die afgelope vier, vyf dekades wat my spesifiek opgeval het. Ek het binne hierdie konteks onmiddellik gedink aan die geskiedenis van Tydskrif en die langslewendheid daarvan vergelyk met dag- en weekblaaie en literêre tydskrifte wat gekom en gegaan het, met teorieë en tendense wat veld gewen en verloor het, met selfs elektroniese kommunikasietegnieke wat uitgevind is en weer verouder het. En in Willemse se kommentaar waarna reeds hierbo verwys is, het ek die verwoording van my gedagtes tydens daardie intreerede raakgelees, naamlik dat Tydskrif: "'n aaneenlopende rekord bied van ingesteldhede vanaf die vroeë Afrikaanse letterkunde en die verweefdheid van 'n veranderende sosiale omgewing met die veranderende ingesteldhede van skrywers en literatore" (5). Hierin lê vir my die beskrywing van ' $n$ voortreflike voorbeeld van' $n$ 
durende humanisme; van die ware liefde vir die letterkunde gereflekteer in die betrokkenheid by die belangstellings en aspirasies van'n bepaalde tyd.

Maar daar was nog' $n$ uitspraak van Burger wat my gedagtes omtrent Tydskrif aan die loop gesit het, en dit was die stelling dat die letterkunde onvermydelik altyd 'n gesprek met wat voorafgegaan het, inisieer. Dit is voortdurend bewus van tradisie, en die bydrae van die nuwe word altyd geëvalueer in die mate wat dit herdefinieer wat tradisie is. Dat en hoe die Skrywerskring se Die Afrikaanse boek van 1936 die "Tydskrif vir Afrika-letterkunde" (soos wat die huidige subtitel van Tydskrif vir Letterkunde lui) in die 21ste eeu geword het, hou nie alleen verband met die transformasie van agendas en doelwitte nie wat die verloop van tyd noodwendig meebring, maar bied tegelykertyd ook bewys van hoe elke nuwe redakteur en redaksieraad direk of by implikasie rekening gehou het met die voorgangers en hulle spesifieke tydsgewrig en kulturele omgewing.

Ek het aan die begin gespog omtrent my persoonlike band met al hierdie redakteurs. Dit was egter, soos maar dikwels die geval is, ietwat van'n oordrywing. My pa het in die jare 1943 tot 1945 aan Wits, of soos dit toe amptelik bekend gestaan het, die Randse Universiteit, studeer. Hy het sowel die honneurs- as'n meestersgraad in Afrikaans en Nederlands behaal, sy verhandeling was getitel "Die godsdiens in die poësie" en sy dosente was C. M.van den Heever en Abel Coetzee. Baie jare later was sy antwoord op die vraag waarom hy nie met Afrikaans nie, maar met Geskiedenis voortgegaan het vir'n doktorsgraad dat, en ek parafraseer nou na geheue, "dit twee vrot dosente was. Van den Heever het die grootste deel van die middag by sy lessenaar op sy arms lê en slaap, en Coetzee was altyd besig met ander sake". Dis eers toe ek in Stander se bogenoemde artikel lees van die "gevaarlik vertroulike" Coetzee-brief waarin hy Van den Heever beskryf as "kaalkop lui" en kla dat hy, Coetzee, die Skrywerskring en Tydskrif feitlik alleen moes dra (Stander 26-27), dat ek hierdie uitsprake weer onthou het.

Die derde redakteur, Coenie Rudolph, het ek in 1966 ontmoet toe ek'n diplomastudent aan die Pretoriase Onderwyskollege en hy ons dosent in Afrikaans was. So pas gegradueer, het' $n$ paar van ons nogal ' $n$ hoë dunk van ons eie kennis en slimmighede gehad en nie veel aandag aan die diploma-onderrig gegee nie. Maar die herinnering aan Koos Meij wat een oggend in die lesinglokaal ingestap en gevra het dat ons vir mnr. Rudolph moet gelukwens met sy aanstelling as redakteur van "'n tydskrif", bly baie helder. Dat ons belhamels nie geweet het na watter tydskrif verwys is nie, was tot ons eie nadeel.

Omtrent die daaropvolgende drie redakteurs kan ek met meer kundigheid praat. Elize Botha, Henning Pieterse en Hein Willemse is vir my sinoniem met Tydskrif en sy huidige hoë status en elkeen van hulle het, soos ek dit sien, daardie "verweefdheid van veranderde sosiale en kulturele omstandighede by wyse van die letterkundige bedryf" (Willemse 5) op unieke wyse deur hulle redakteurskap gereflekteer. 
Elize Botha het die vierde redakteur van Tydskrif geword in 1973, die jaar wat ek onder haar leiding vir die D.Litt-graad geregistreer het. Haar aanstelling het ironiese kommentaar gelewer op die Skrywerskring se aanvanklike posisie dat vroue nie lidmaatskap mag kry nie, en dus, soos Elisabeth Eybers dit gestel het, eintlik as "Die Johannesburgse Vereniging vir Manlike Belangstellendes in die Letterkunde" (Kannemeyer 169) bekend moes staan. Gedurende die volgende byna twintig jaar het Botha volgens haar besondere persoonlikheid en aard-uitermate sjarmant, lief vir geselskap, nooit konfronterend, belese in die wêreldletterkunde maar sonder weerga in haar liefde vir die Afrikaane teks, en veral die prosa-haar stempel op die tydskrif en sy inhoud afgedruk. Ek weet uit persoonlike gesprekke met hoeveel deernis sy bydraers en bydraes hanteer het; hoe sy individue aangespoor het om werk (kreatief en krities) vir publikasie voor te lê; hoe die gereelde byeenkomste van die redaksielede by haar aan huis hoogtepunte van akademiese en sosiale kommunikasie was. Maar ek vereenselwig Elize Botha se redakteurskap met veral drie prestasies. In hierdie twee dekades, en met die groot ondersteuning van Piet Roodt en Elsa Nolte as redaksielede, het die afdeling "Voorgeskrewe boeke vir Matriek" tot'n werklik sinvolle deel van die tydskrif se inhoud ontwikkel. Hierdie deeglike besprekings deur ervare letterkundiges het nou aangesluit by die handboeke geskryf deur onder meer Botha en Grové (byvoorbeeld Handleiding by die studie van die letterkunde en Woord en wonder), en'n brug geslaan tussen die toe nog grotendeelse memoriseringsmetodiek op skool en die toenemende analitiese en teoreties-gefundeerde onderrig op universiteitsvlak. Vir die liefhebber van die Afrikaanse letterkunde was dit veral die tydskrif se fokus op die publikasie van nuwe, jonger skrywers, en veral prosaskrywers: Hennie Aucamp, Jaap Steyn, Alexander Strachan en die Tagtiger-generasie wat hierdie periode gekenmerk het. En in die laaste plek moet die nouer verbintenisse met veral die Vlaamse maar in'n mate ook die Nederlandse literêre circuit op hierdie redakteur se rekening geplaas word. Haar persoonlike netwerk opgebou gedurende haar studietyd in Amsterdam het daartoe bygedra dat in hierdie akademiese boikotjare die samewerking steeds positief was en die band wat in die huidige tydvak so produktief is, nie uitgerafel het nie. Dit was dan ook Marcel Janssens, daardie reus van die Vlaamse kultuurlewe, wat finansiering gereël het in'n tyd wat Tydskrif byna bankrot was en wat self daarna op die redaksieraad gedien en gereeld akademiese bydraes gelewer het.

In 1993 het Henning Pieterse die nuwe redakteur geword. Hy was toe my kollega in die Department Afrikaans by Unisa, en soos dit maar met interne departmentele politiek gaan, is hierdie aanstelling nie net as 'n pluimpie vir die hele department beskou nie, maar het baie van sy kollegas ook gewonder hoe Henning die nuwe werklas saam met sy soms massas sieldodende merkwerk sou versoen. My herinnering is dat dit'n suksesvolle versoening was, maar my helderste beeld is van Henning wat agter sy lessenaar sit en net-net sigbaar is bo-oor die opgehoopte manuskripte en nog 
onoopgemaakte koeverte, en van die posbode wat byna daagliks arms vol nuwe koeverte na Henning aandra. Ten spyte van Tydskrif se eie posadres, het die toeloop ook na Unisa oorgespoel: manuskripte waarmee onder Henning se redakteurskap, en met redaksielede soos Joan Hambidge en steeds Piet Roodt, Tydskrif'n nuwe fase sou betree; een waartydens die fokus op nuwe stemme in die poësie sou val. In die afwesigheid van Standpunte waarvan publikasie reeds in 1986 gestaak is, sou Tydskrif die enigste stabiele platform vir jong digters word. Die geleenthede wat Tydskrif toe geskep het, het uitlopers na baie ander terreine gehad: die bekgevegte op spontane byeenkomste en by kunstefeeste; later die bekendstelling van digters en hulle digwerk in alle Suid-Afrikaanse tale op die program "Nuwe stemme / New voices" wat ons vir 'n paar jaar in die Department Afrikaans by Unisa met behulp van Pieterse kon aanbied. Ek wonder in hoe' $n$ groot mate Henning se huidige betrokkenheid by die onderrig van kreatiewe skryfkuns en die entoesiasme van sy huidige studente uit hierdie jare as Tydskrif-redakteur gegroei het.

En dit bring my by die huidige redakteur, my gewaardeerde kollega en vriend Hein Willemse. Met sy leierskap is Tydskrif op talle gebiede binne'n nuwe bestel en'n nuwe tydvak ingelei. Dat Tydskrif nou "'n Tydskrif vir Afrika-letterkunde" geword het, is sigbaar in die interessante, kleurvolle voorblaaie-my persoonlike gunsteling is die een waardeur die werk van Amos Langdown gehuldig word (43:2, Lente 2006), in die lys van die redaksielede wat mans en vroue van oor die hele wêreld verteenwoordig (en nie meer die noordelike "kultuur-ollannas" (Stander 19) omtrent wie die suidelike W.E.G. Louw so snedig geskryf het), deur die boeiende temanommers waaronder ek self betrokke was as gasredakteur van die nommer oor die (Belgiese) Kongo in die literatuur (46:1, Herfs 2009). Waar die eerste redaksieraad in 1936 moeisaam kontak met die buitewêreld gemaak het deur die Skrywerskring se ongemaklike affiliasie met PEN en waar slegs op die Vlaamse Vereniging van Letterkundiges se goeie wense gereken kon word, beklee Tydskrif vandag werklik'n integrale posisie binne' $n$ postkoloniale wêreld. Sekere bande is versterk (ek lees in die Lenteuitgawe van 2011 die huldeblyk aan die Franstalige Karibiese digter-filosoof Édouard Glissant geskryf deur die Vlaamse Kathleen Gyssels), nuwes is opgebou (veral die met Afrika-kulture en letterkundes deur' $n$ uitbreiding van die taalmedium en deur temanommers), ander is opsigtelik verbreek—soos dit blyk wanneer Willemse se sterk verklaring omtrent die standpunt van Tydskrif teen sensuur-en publikasiebeheer vergelyk word met die redaksie van die sewentigerjare se "angstigheid om nie die owerhede te irriteer nie" (Stander 23).

My blywende indruk van Tydskrif en sy opeenvolgende redakteurs is hoe daar aangesluit is by die merkwaardige tradisie van die letterkunde om teen tradisie in te skryf terwyl altyd rekening gehou word met daardie tradisie. Die mooi ideale van die stigterslede-uiteengesit in ' $n$ notule van die stigtersvergadering (Stander 14) - is meer as verwesenlik, onder andere omdat wat parogiaal en amateuragtig was, 
ontwikkel het tot'n produk met hoogstaande internasionale gesag. Dis min 75-jariges wat so selfversekerd die toekoms kan betree; kom ons wens almal van die opeenvolgende redaksies en die medewerkers deur die jare, maar ook onsself, as lesers, geluk daarmee!

\section{Geraadpleegde bronne}

Botha, Elize. "Die Tydskrif vir Letterkunde en die Vlaamse verbintenis." Tydskrif vir Letterkunde XXXVI/ XXXVII.4 (1998/1999): 1-10.

Botha, Elize en Roodt, P. H. “Die Tagtigers en die Tydskrif vir Letterkunde-was daar'n Tagtigerbeweging?" Tydskrif vir Letterkunde 43.1 (2006): 57-67.

Burger, Willie. "'Betrokke kritiek'-Literatuurkritiek wat die wêreld verander? Literatuurkritiek ná teorie." U van Pretoria. 1 Sept. 2011. Professorale intreerede.

Kannemeyer, J. C. Die dokumente van Dertig. Kaapstad: Juta, 1990.

Stander, Jan. "75 jaar van Tydskrif vir Letterkunde_-'n voorlopige verkenning." Tydskrif vir Letterkunde 48.2 (2011): 13-30.

Willemse, Hein. "Tydskrif vir Letterkunde: 'n Aaneenlopende rekord van 75 jaar." Tydskrif vir Letterkunde 48.2 (2011): $5-8$ 